\title{
Odorant-Evoked Increase in Cytosolic Free Calcium in Cultured Antennal Neurons of Blowflies
}

\author{
Azusa Nakagawa-Inoue ${ }^{1 *}$, Shigenori Kawahara ${ }^{2}$, Yutaka Kirino ${ }^{2}$ \\ and Tatsuhiko Sekiguchi ${ }^{1}$ \\ ${ }^{1}$ Tsukuba Research Center, SANYO Electric Co., Ltd., \\ Tsukuba, Ibaraki 305, Japan \\ ${ }^{2}$ School of Pharmaceutical Sciences, The University of Tokyo, \\ Hongo 7-3-1, Tokyo 113, Japan
}

\begin{abstract}
The responses of cultured antennal neurons of blowflies to odorants, ethyl acetate and isovaleric acid, were measured using fura-2, a calcium-sensitive fluorescent dye. Both odorants induced increases in cytosolic free calcium concentration $\left(\left[\mathrm{Ca}^{2+}\right]_{\mathrm{i}}\right)$ in the neurons. The peak $\left[\mathrm{Ca}^{2+}\right]_{i}$ was 1.1 to 7.5 times as high as $\left[\mathrm{Ca}^{2+}\right]_{i}$ of the resting neurons. The increase in $\left[\mathrm{Ca}^{2+}\right]_{i}$ occurred within $10 \mathrm{sec}$ after exposure to the odorants in most neurons. It, however, occurred up to $110 \mathrm{sec}$ after the odorant exposure in some neurons. As $\left[\mathrm{Ca}^{2+}\right]_{\mathrm{i}}$ increase was diminished upon removing $\mathrm{Ca}^{2+}$ from saline, $\left[\mathrm{Ca}^{2+}\right]_{i}$ increase was assumed to be due to $\mathrm{Ca}^{2+}$ influx. $\left[\mathrm{Ca}^{2+}\right]_{i}$ increase was also induced by introducing forskolin and membrane-permeable analogues of cyclic AMP and GMP.
\end{abstract}

\section{INTRODUCTION}

In insects, olfaction is a very important sensory modality because it is used to detect chemical substances associated with mating and food foraging. Olfactory transduction is thought to be mediated by membrane-bound receptor initiating a multistep reaction cascade that leads to generation of action potentials in olfactory receptor neurons (ORNs). Biochemical studies and extracellular electrophysiological recordings have succeeded in clarifying the mechanisms of insect olfaction, but have primarily concentrated on understanding how pheromones elicit receptor potentials in ORNs (Boekhoff et al., 1990; Breer et al., 1990; Ziegelberger et al., 1990; Stengl et al., 1992; Stengl, 1993, 1994). However, the transduction mechanism of non-specific odors other than pheromones remains elusive.

Primary cell cultures are useful for studying the functions of individual ORNs. In insects, ORNs are located within the sensilla on antennae covered with hard cuticle, and are extremely small and closely surrounded by supporting cells. Therefore, insect ORNs in situ are amenable neither to experiments using intracellular or patch-clamp recording electrodes nor to optical recording techniques using potential-sensitive or $\mathrm{Ca}^{2+}$-sensitive dyes. We have established the methods for primary cell culture of blowfly antennal cells and for morphological and immunocytochemical identification of cultured neurons in previous study (Nakagawa and Iwama, 1995). These cultured neurons will provide important information on

\footnotetext{
* Corresponding author: Tel. +81-298-37-2812; FAX. +81-298-37-2833.
}

the physiology of antennal ORNs.

In this study, we applied the optical imaging technique to cultured ORNs using fura-2, a $\mathrm{Ca}^{2+}$-sensitive dye, and examined the responses of ORNs to odorants and cyclic nucleotide analogues that are thought to mediate olfactory transduction.

\section{MATERIALS AND METHODS}

\section{Animal maintenance and cell culture}

Blowflies (Phormia regina, Meigen) were reared in the laboratory as described in our earlier paper (Nakagawa and Iwama, 1995). Cell culture was performed in accordance with the method described previously (Nakagawa and Iwama, 1995). In brief, antennae of 4-dayold blowfly pupae were disrupted by enzymatic treatment with papain and trituration. The dispersed cells were plated on Con-A-coated dishes in L15 medium (Gibco) supplemented with 100 units/ml penicillin, $100 \mu \mathrm{g} / \mathrm{ml}$ streptomycin, $50 \mathrm{mM}$ trehalose, $10 \%$ fetal bovine serum and approximately $1 \mu \mathrm{g} / \mathrm{ml} 20$-hydroxyecdysone (Sigma).

\section{Fluorescence imaging of intracellular calcium}

Antennal neurons plated on Con-A-coated glass bottom culture dishes (35 mm, MatTek) were incubated in the culture medium at $29^{\circ} \mathrm{C}$. Cells cultured for 1-2 days were used for the experiments.

After cells had been washed with saline $(\mathrm{NaCl} 156 \mathrm{mM}, \mathrm{KCl} 4$ $\mathrm{mM}, \mathrm{CaCl}_{2} 6 \mathrm{mM}$, glucose $5 \mathrm{mM}, \mathrm{HEPES} / \mathrm{NaOH} 10 \mathrm{mM}, \mathrm{pH}$ 7.1), the cells were incubated in the saline with $40 \mu \mathrm{M}$ fura-2/acetoxymethyl (fura-2/AM) (Molecular Probes) with 0.2\% Pluronic F-127 (Molecular Probes) for $1 \mathrm{hr}$ at $29^{\circ} \mathrm{C}$. Thereafter, the cells were washed with saline and incubated for $30 \mathrm{~min}$ at $29^{\circ} \mathrm{C}$.

Cultured antennal neurons did not take up fura-2/AM easily. Optimum condition for dye loading to the cultured antennal neurons was $40 \mu \mathrm{M}$ fura-2/AM for $1 \mathrm{hr}$ at $29^{\circ} \mathrm{C}$.

After loading with fura-2, the cells in a dish containing saline were 
mounted on the stage of an inverted microscope (IX-70, Olympus) equipped with a $40 \mathrm{X}$ objective lens and a Xe lamp (75 W). Images were obtained using a microcomputer-assisted imaging device system (MCID, Imaging Research, Ltd.) and an intensified charge-coupled device (ICCD) camera. Wavelengths of an excitation light used in this study were 340 and $380 \mathrm{~nm}$ and were switched at $50 \mathrm{msec}$ intervals each other.

The cells were continuously perfused with saline, and odorants or chemicals were sequentially applied for $10 \mathrm{sec}$ using a peristaltic pump. The flow rate was $1.8 \mathrm{ml} / \mathrm{min}$ and solution volume in the chamber was maintained at approximately $300 \mu \mathrm{l}$. For removal of extracellular $\mathrm{Ca}^{2+}$, normal saline was replaced with $\mathrm{Ca}^{2+}$-free saline. $\mathrm{Ca}^{2+}$-free saline was prepared by replacing $\mathrm{Ca}^{2+}$ with $\mathrm{Mg}^{2+}$ in normal saline and adding $1 \mathrm{mM}$ EGTA to it.

After exposure to odorants or chemicals, the cells were treated with a high $-\mathrm{K}^{+}$saline in which the concentration of $\mathrm{KCl}$ was 2.5 times higher than that in normal saline, i.e., $20 \mathrm{mM}$. At least 3 types of cells were recognized in antennal cell cultures (Nakagawa and Iwama, 1995). Among these, the antennal neurons were easily identified by their morphology. These neurons are large and small in size, suggesting the presence of different classes of sensory neurons with different modalities such as olfactory and mechanosensory. However, ICCD camera images were not clear enough to discriminate the antennal neurons from other cells and debris in the cultures. In addition, some neurons died or were detached from the culture dishes during the experiments. Thus, the cells that showed increase in $\left[\mathrm{Ca}^{2+}\right]_{i}$ in response to the application of high- $\mathrm{K}^{+}$saline were used for data analysis. The responses of the cells are expressed as the ratio between emissions at $340 \mathrm{~nm}$ and $380 \mathrm{~nm}$.

\section{Stimuli}

Ethyl acetate (EA) and isovaleric acid (IVA) which were diluted with normal or $\mathrm{Ca}^{2+}$ free saline were used as odorant stimuli. EA and IVA were selected because of the difference in their odor qualities: EA has a fruity and pleasant odor, whereas IVA is putrid. For the cases where extracellular $\mathrm{Ca}^{2+}$ was removed, odorants were diluted with $\mathrm{Ca}^{2+}$-free saline. Forskolin and the membrane-permeable cyclic nucleotide analogues, $\mathrm{N}_{6}, 2^{\prime}$-O-dibutyryl adenosine (guanosine) 3',5'cyclic monophosphate (dib-cAMP and dib-cGMP), were stocked in solutions dissolved in dimethyl sulfoxide. These stock solutions were added to the saline to obtain desired concentrations.

(A)

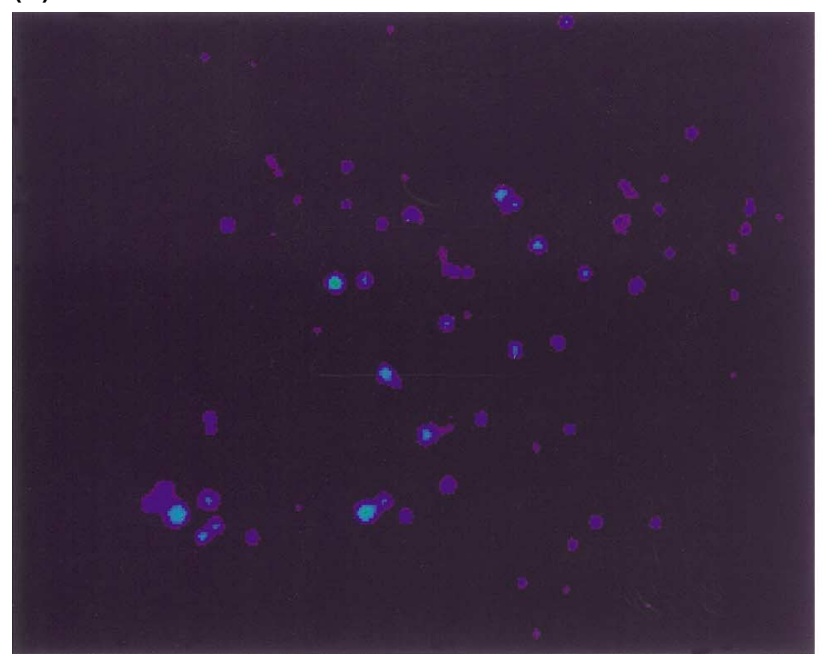

\section{RESULTS}

In the culture, antennal neurons began to extrude processes within a few hours after dissociation and plating. After overnight culture, most of the antennal neurons had a single prominent neurite and several short processes arising from the soma (Fig. 1).

After loading with fura-2, antennal neurons were stimulated by the odorants. Figure 2 shows fluorescence images of cultured antennal neurons. Thirty three percent of the cultured antennal neurons showed an increase in $\left[\mathrm{Ca}^{2+}\right]_{\mathrm{i}}$ by stimulation with $100 \mu \mathrm{M} \mathrm{EA} \mathrm{(67} \mathrm{among} 211$ neurons), and $81 \%$ of the neurons increased $\left[\mathrm{Ca}^{2+}\right]_{i}$ by stimulation with $100 \mu \mathrm{M}$ of IVA (118 among 146 neurons) (Fig. 3). [ $\left.\mathrm{Ca}^{2+}\right]_{i}$ increased within 10 sec after application of the odorants, and slowly declined after reaching its peak. The peaks of $\left[\mathrm{Ca}^{2+}\right]_{\mathrm{i}}$ in response to 100 $\mu \mathrm{M}$ EA and $100 \mu \mathrm{M}$ IVA were $2.1 \pm 0.9$-fold (mean \pm S.D., $\mathrm{n}=$ $13)$ and $1.9 \pm 1.2$-fold $(n=29)$ the resting value, $157.5 \pm 150.4$ $\mathrm{nM}$, respectively. No significant difference was found between the $\left[\mathrm{Ca}^{2+}\right]_{i}$ peaks for EA and IVA ( $p>0.05$, Mann-Whitney U-

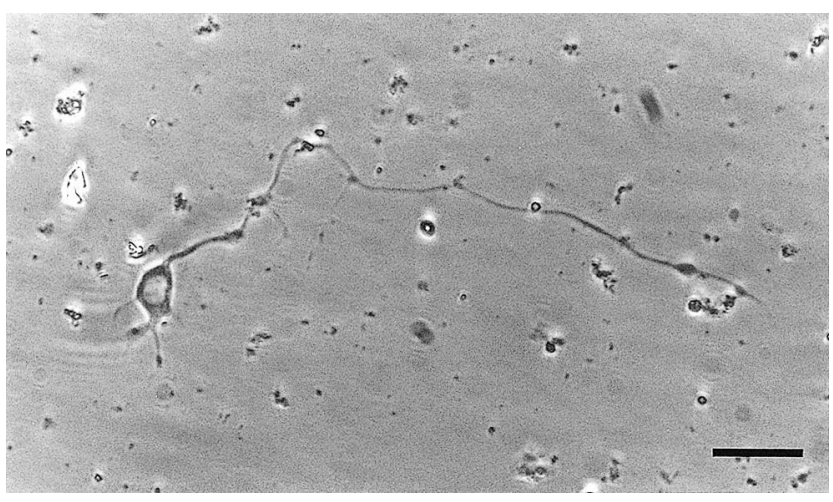

Fig. 1. Antennal neurons in one-day culture. The cells extruded processes within a few hours of culture. Antennal neuron has one prominent long process and several short ones in this micrograph. Scale bar, $20 \mu \mathrm{m}$.

(B)

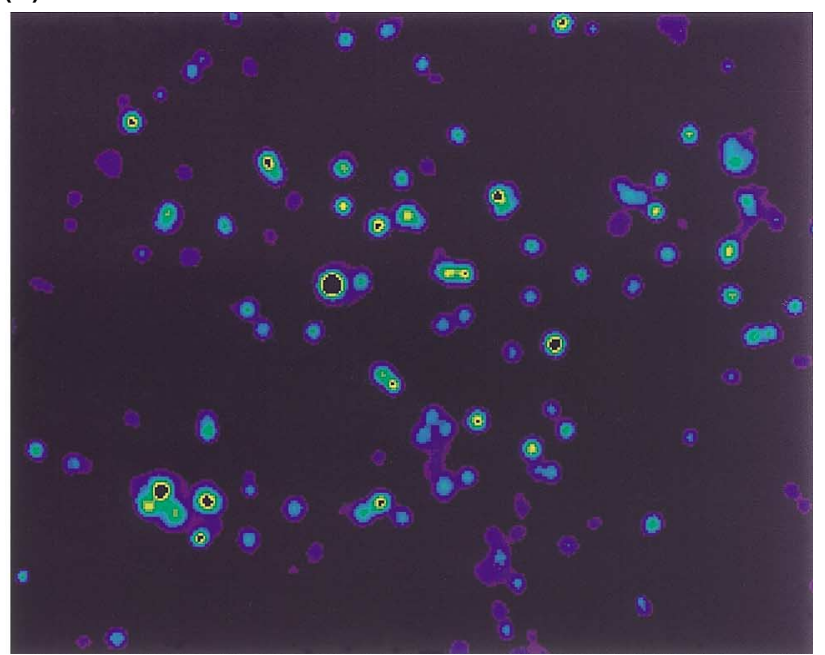

Fig. 2. Fluorescence imaging of cultured antennal neurons with fura-2, a calcium indicator. (A) Fluorescence ratio (340 nm/380 nm) of image of cells immediately after loading fura-2. (B) An increase in fluorescence ratio was observed after odorant stimulation. 


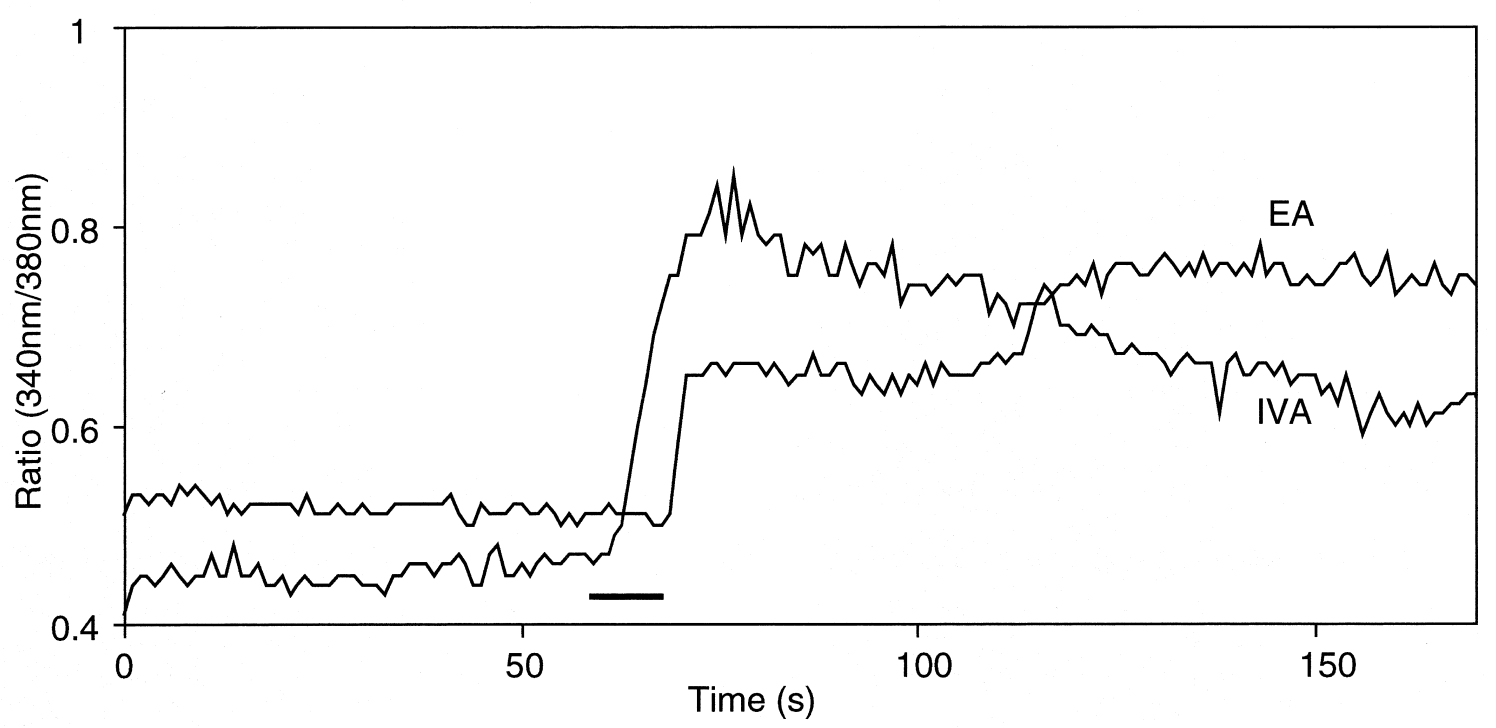

Fig. 3. Increases in $\left[\mathrm{Ca}^{2+}\right]_{i}$ in cultured antennal neurons in response to odorants. One hundred $\mu \mathrm{M}$ ethyl acetate (EA) or isovaleric acid (IVA) was applied by perfusion for $10 \mathrm{sec}$. The timing of application is indicated by the bar.

(A)
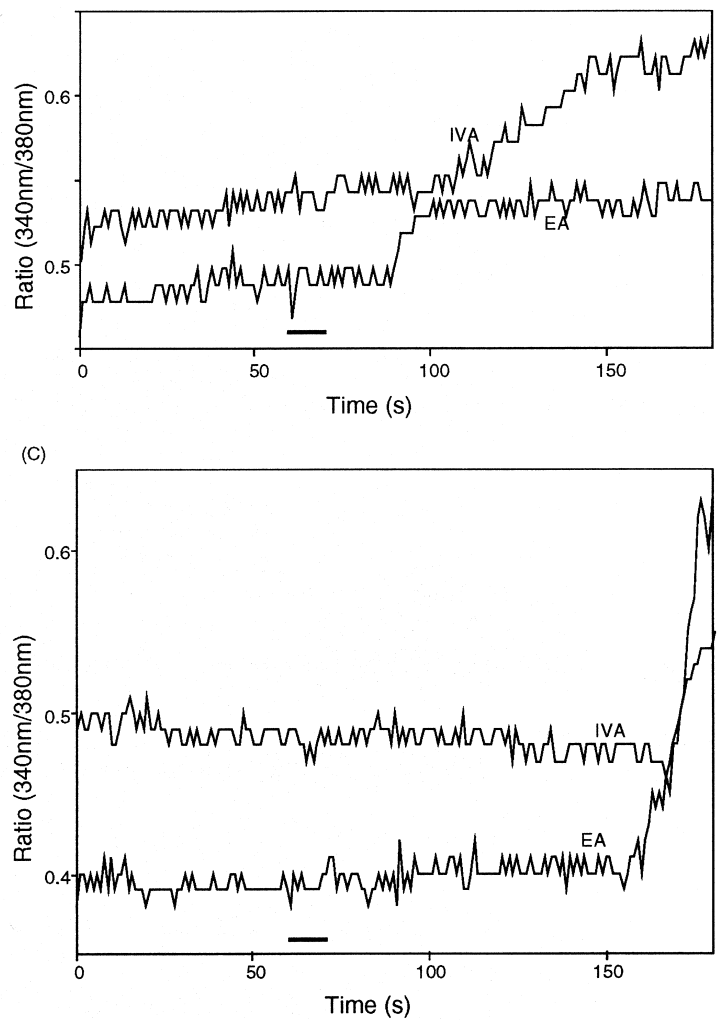

(B)

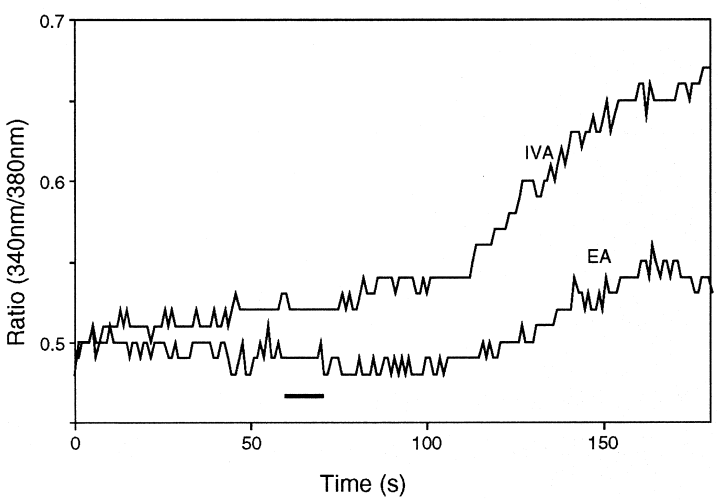

(D)

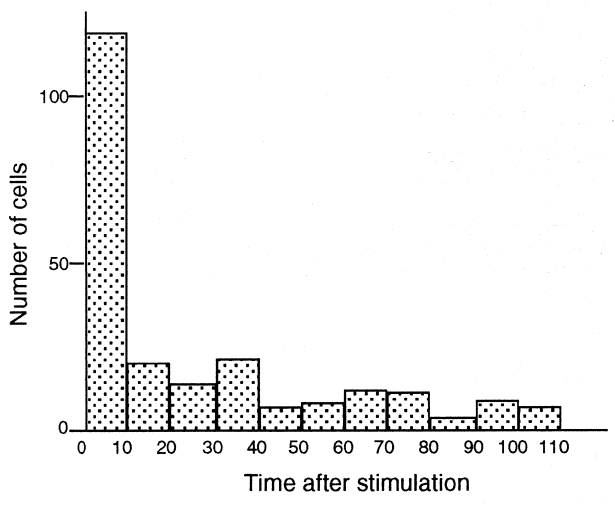

Fig. 4. Time course of $\left[\mathrm{Ca}^{2+}\right]_{i}$ increases in cultured antennal neurons in response to odorant stimulations. Some neurons responded to either EA or IVA stimulus with long latencies. Various latencies were observed. (A) An increase in [Ca $\left.{ }^{2+}\right]_{i}$ appeared about 30 to 40 sec after stimulation. Responses were also observed after latencies of 60 to $70 \mathrm{sec}$ (B) or more than $90 \mathrm{sec}$ (C). The timing of stimulation is indicated by bars. (D) Latency histogram of neurons is shown. 

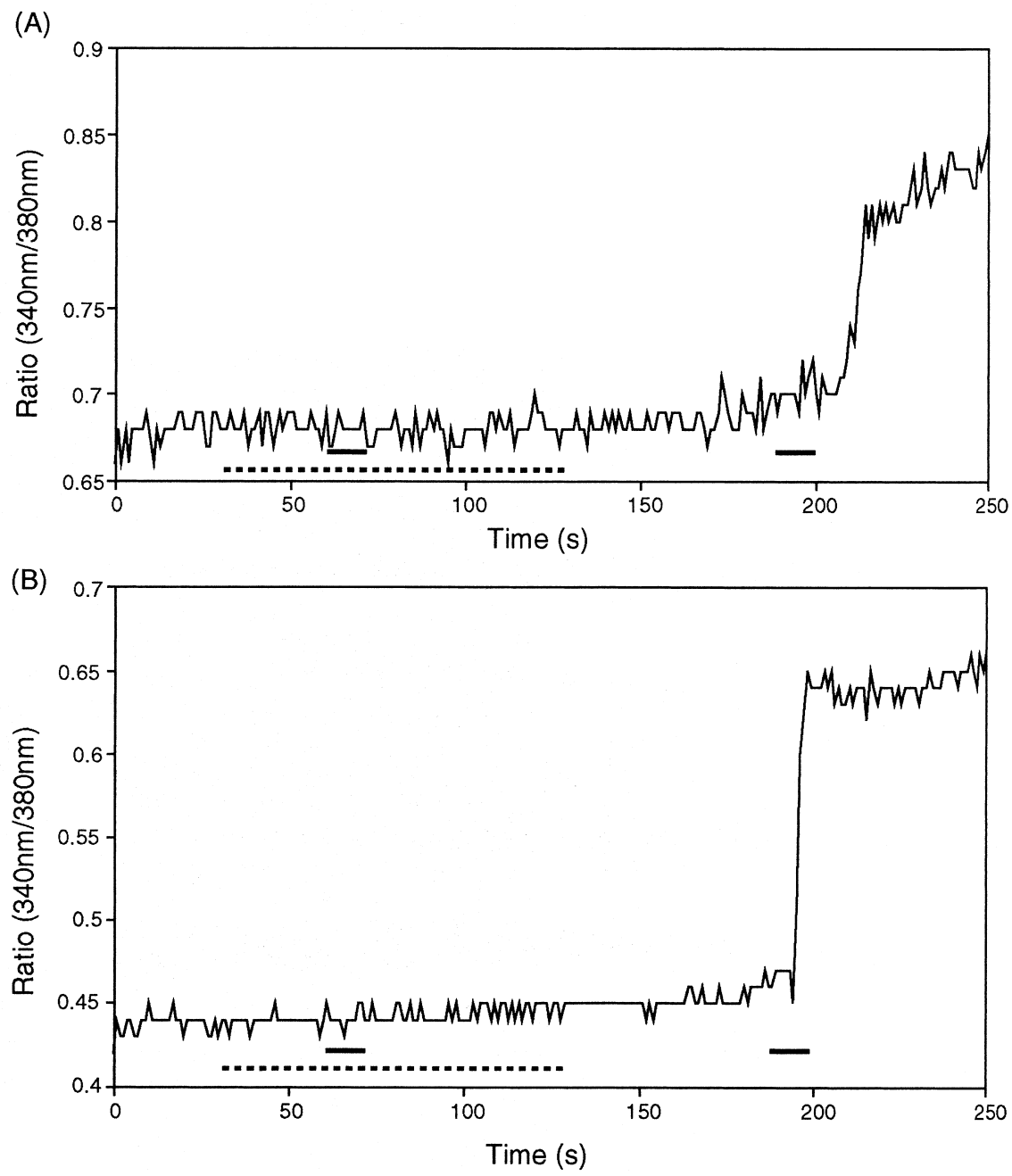

Fig. 5. Effect of extracellular $\mathrm{Ca}^{2+}$ on response to odorants of cultured antennal neurons. Odorants were applied to cultured neurons in $\mathrm{Ca}^{2+}{ }_{-}$ free saline. In the absence of extracellular $\mathrm{Ca}^{2+}$, no increase in $\left[\mathrm{Ca}^{2+}\right]_{\text {i }}$ was elicited by either EA (A) or IVA (B). After washing with normal saline, the response to odorants was restored. Odorants were applied at the timing shown by solid bars. Dotted bars indicate the periods when extracellular $\mathrm{Ca}^{2+}$ was removed from bath solution.

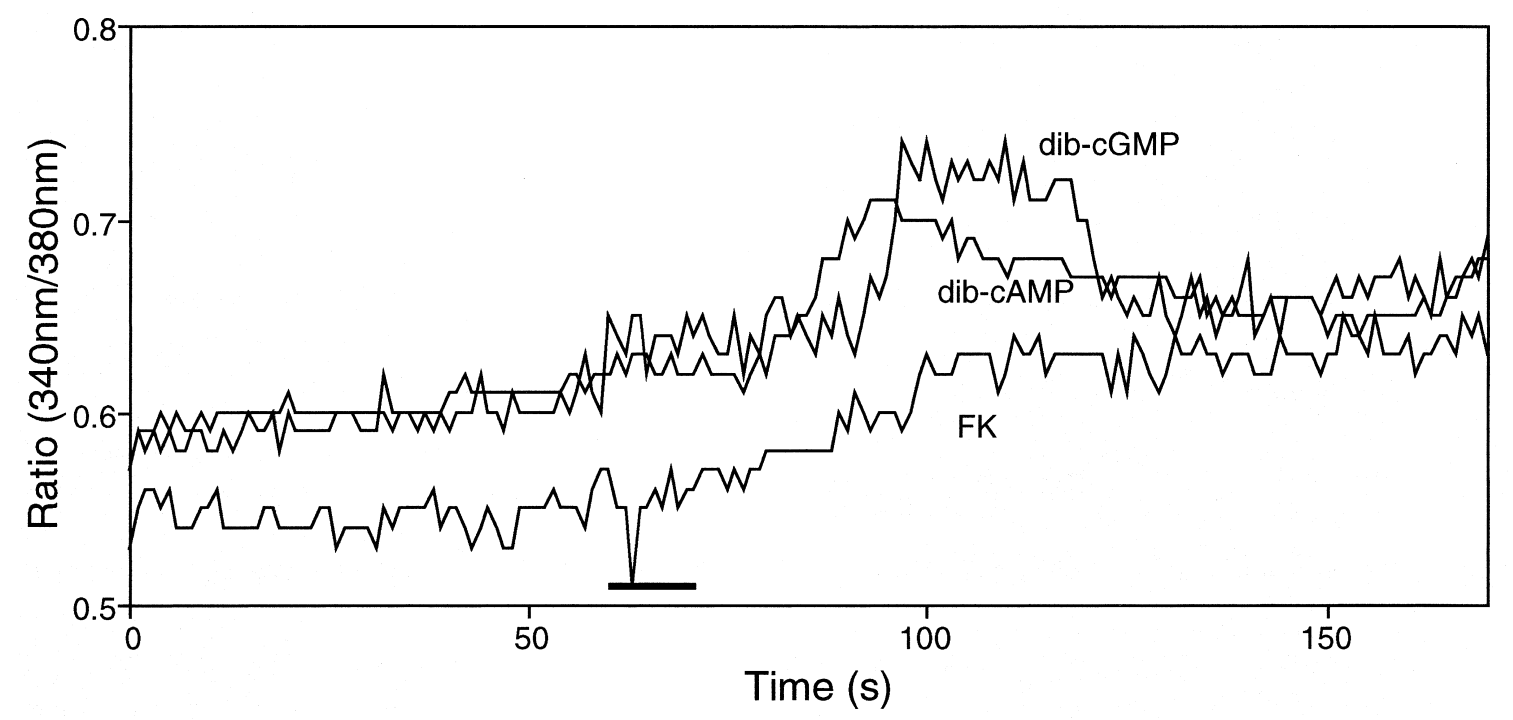

Fig. 6. Effects of forskolin (FK) and membrane-permeable cyclic nucleotide analogues, dib-cAMP and dib-cGMP, on [Ca $\left.{ }^{2+}\right]_{i}$ in cultured antennal neurons. FK, dib-cAMP and dib-cGMP elicited increases in $\left[\mathrm{Ca}^{2+}\right]_{i}$ in cultured antennal neurons. The timing of stimulation by each substance is shown by bar. 
test). The mean peak of $\left[\mathrm{Ca}^{2+}\right]_{i}$ of the two odorants was $1.9 \pm$ 1.2-fold the resting value $(n=41)$.

The time of rising phase (the time from the beginning of increase to peak of the $\left.\left[\mathrm{Ca}^{2+}\right]_{\mathrm{i}}\right)$ was $31.7 \pm 19.8 \mathrm{sec}$ in response to $100 \mu \mathrm{M}$ EA $(n=24)$ and $22.9 \pm 16.3 \mathrm{sec}$ in response to $100 \mu \mathrm{M}$ IVA ( $n=27)$. The rising phase appeared to be slightly longer in response to EA than in response to IVA, but no significant difference was present between them $(p>$ 0.05, Mann-Whitney U-test).

Low concentrations of odorants $(10 \mu \mathrm{M})$ also induced an increase in $\left[\mathrm{Ca}^{2+}\right]_{\text {, }}$, but were less effective than $100 \mu \mathrm{M}(20 \%$ and $70 \%$ of the neurons responded to $10 \mu \mathrm{M}$ EA and IVA, respectively ( $n=50, n=13)$.

The latency, period between stimulus onset and beginning of $\left[\mathrm{Ca}^{2+}\right]_{i}$ increase, was very short in most neurons but was varied widely up to $100 \mathrm{sec}$ in other neurons in Fig. 4D. For example, the latency was $30-40 \mathrm{sec}$ in Fig. 4A, 60 - 70 $\mathrm{sec}$ in Fig. 4B and more than $90 \mathrm{sec}$ in Fig. 4C. Figure 4D shows the distribution of latencies after stimulation.

To investigate whether $\mathrm{Ca}^{2+}$ influx contributes to the increase in $\left[\mathrm{Ca}^{2+}\right]_{i}$, neurons were stimulated with odorants in the absence of extracellular $\mathrm{Ca}^{2+}$. When the bath solution was replaced by $\mathrm{Ca}^{2+}$-free saline, no increase in $\left[\mathrm{Ca}^{2+}\right]_{\mathrm{i}}$ was elicited by stimulation with either odorant. After reintroducing $\mathrm{Ca}^{2+}$ into the bath solution, however, both odorants were observed to evoke increases in $\left[\mathrm{Ca}^{2+}\right]_{i}(n=12$ for $\mathrm{EA}, \mathrm{n}=13$ for IVA) (Fig. 5). These results suggest that influx of extracellular $\mathrm{Ca}^{2+}$ is involved in the $\left[\mathrm{Ca}^{2+}\right]_{\mathrm{i}}$ increase.

Forskolin (FK), which is used to increase intracellular cAMP level, and dib-cAMP and dib-cGMP were tested for their effects on $\left[\mathrm{Ca}^{2+}\right]_{i}$ in cultured antennal neurons. Figure 6 shows the responses of cells to each of these substances. Fortyeight percent of the neurons showed an increase in $\left[\mathrm{Ca}^{2+}\right]_{i}$ by stimulation with $10 \mu \mathrm{M} \mathrm{FK}(\mathrm{n}=61)$. As for membrane-permeable nucleotide analogues, $61 \%$ of the neurons increased $\left[\mathrm{Ca}^{2+}\right]_{i}$ by 5 or $10 \mathrm{mM}$ of dib-cAMP $(\mathrm{n}=33)$, and $64 \%$ of the neurons increased $\left[\mathrm{Ca}^{2+}\right]_{i}$ by $10 \mathrm{mM}$ of dib-cGMP $(\mathrm{n}=67)$. Most neurons showed $\left[\mathrm{Ca}^{2+}\right]_{i}$ increases soon after stimulation by these three chemicals. Some neurons showed a delayed response similar to that to odorant stimulation. $\left[\mathrm{Ca}^{2+}\right]_{i}$ following stimulation by these chemicals were 1.1- to 4.8-fold (mean was $1.8 \pm 0.8$-fold, $n=23$ ) of the resting level.

\section{DISCUSSION}

The mean resting $\left[\mathrm{Ca}^{2+}\right]_{\mathrm{i}}$ in cultured blowfly antennal neurons is $157.5 \mathrm{nM}$. This value is much higher than ones in catfish (Restrepo et al., 1990) and frog (Sato et al., 1991) ORNs (23 nM and $38 \mathrm{nM}$, respectively). We used antennal neurons cultured for 1-2 days after dissociation. These neurons were at the stage of extruding processes (Nakagawa and Iwama, 1995). A previous study has suggested a positive correlation between cell growth and high $\left[\mathrm{Ca}^{2+}\right]_{i}$ (Connor, 1986). It has also been demonstrated by others that $\left[\mathrm{Ca}^{2+}\right]_{i}$ and growth are closely related and $\left[\mathrm{Ca}^{2+}\right]_{i}$ level is limited during cell growth (Mattson and Kater, 1987; Kater and Mills, 1991; Al-Mohanna et al.,1992). The high resting $\left[\mathrm{Ca}^{2+}\right]_{\mathrm{i}}$ in cultured blowfly antennal neurons could be related to the stage of cell growth.

Cultured blowfly antennal neurons showed increases in $\left[\mathrm{Ca}^{2+}\right]_{i}$ after stimulation with either EA or IVA. $\left[\mathrm{Ca}^{2+}\right]_{i}$ of most neurons increased soon after the application of the odorant stimulus and continued to be higher than the prestimulus value for about $30 \mathrm{sec}$. These results are similar to those reported for frog (Sato et al., 1991). Blowfly ORNs are bipolar neurons with one end giving rise to the axon and the other forming the dendrite. Cultured antennal neurons, in many cases, have one prominent long process and several short ones (Nakagawa and Iwama, 1995). Therefore, these neurons may function as an olfactory system with different sensitivity or specificity to odors compared with the in situ ORNs of blowflies. However, it is unlikely that at least the $\left[\mathrm{Ca}^{2+}\right]_{\mathrm{i}}$ response is influenced by the morphology.

Our results showed that some populations of cultured antennal neurons of blowfly responded to each odorant: $33 \%$ and $81 \%$ of neurons responded to EA and IVA, respectively. The question whether single neurons respond to and discriminate between different odors remains. Previous studies on vertebrate ORNs with various odorants having different molecular structures and odor qualities have demonstrated that single ORNs respond to various odorants (Sicard, 1985; Firestein et al., 1993; Raming et al., 1993). Single cultured antennal neurons respond to both EA and IVA though it is not known that they recognize the difference in odor qualities between the two.

EA and IVA used in this study are odorants with a different quality for vertebrates: EA has a fruity and pleasant odor, while IVA is putrid. Several studies demonstrated the difference in responses to odors in vertebrates by odor quality. Sklar et al. (1986) showed that pleasant-smelling odorants stimulated adenylate cyclase while putrid odorants had no such effect. It was also reported that pleasant-smelling but not putrid odorants enhanced cAMP levels in olfactory cilia, while putrid odorants increased inositol trisphosphate $\left(\mathrm{IP}_{3}\right)$ levels (Boekhoff et al., 1990; Breer et al., 1990). In contrast, Ronnett et al. (1993) observed the enhancement of phosphoinoisitide turnover by all odorants examined. No significant differences in $\left[\mathrm{Ca}^{2+}\right]_{i}$ increase in response to EA and IVA stimulations was noted in cultured antennal neurons of blowfly, suggesting that $\left[\mathrm{Ca}^{2+}\right]_{i}$ dynamics is independent of the quality of odor. However, since we only compared odorants at a few concentrations (10 or $100 \mu \mathrm{M})$, it is possible that odorants at different concentrations might induce different $\left[\mathrm{Ca}^{2+}\right]_{i}$ dynamics in antennal neurons. In addition, it is not examined whether blowfly olfaction recognizes the qualities of EA and IVA the same as vertebrates do. Further investigation accompanied by behavioural studies will be necessary.

To determine the mechanism mediating $\left[\mathrm{Ca}^{2+}\right]_{i}$ increase, we investigated the effect of extracellular $\mathrm{Ca}^{2+}$ removal on the odor-evoked response. No responses to odorants were observed in the absence of extracellular $\mathrm{Ca}^{2+}$. There are many mechanisms that mediate the $\left[\mathrm{Ca}^{2+}\right]_{i}$ increase, e.g., cAMPgated channels (Suzuki, 1989), IP I $_{3}$-gated channels (Restrepo 
et al., 1990), voltage-dependent $\mathrm{Ca}^{2+}$ channels and $\mathrm{Ca}^{2+}$ release from intracellular $\mathrm{Ca}^{2+}$ stores. The present study on the cultured antennal neurons revealed that at least the influx of extracellular $\mathrm{Ca}^{2+}$ is required for $\left[\mathrm{Ca}^{2+}\right]_{i}$ increases in response to odorant stimulation.

Olfactory transduction is known to be mediated by various cellular mechanisms. In particular, the cAMP pathway is considered to play an important role in olfactory transduction (Pace et al., 1985; Sklar et al., 1986; Nakamura and Gold, 1987; Suzuki, 1989; Boekhoff et al., 1990; Frings and Lidemann, 1990). The cultured antennal neurons showed $\left[\mathrm{Ca}^{2+}\right]_{\mathrm{i}}$ increase following $\mathrm{FK}$ stimulation, which increases intracellular cAMP levels, and following stimulation with a membrane-permeable cAMP analogue, dib-cAMP. These results suggest that $\mathrm{CAMP}$ is involved in $\left[\mathrm{Ca}^{2+}\right]_{i}$ increase and that the cAMP pathway probably acts as a messenger system in the cultured antennal neurons. The membrane-permeable cGMP analogue, dib-cGMP, also elicited an increase in $\left[\mathrm{Ca}^{2+}\right]$ in cultured the antennal neurons, suggesting that cGMP may also mediate $\left[\mathrm{Ca}^{2+}\right]_{i}$ increase. A previous study also indicated the involvement of cGMP in insect olfaction (Boekhoff et al., 1990). In addition, recently, the nitric oxide (NO)/ cGMP system has been shown to be involved in vertebrate ORNs (Breer et al., 1992; Lischka and Schild, 1993).

Some neurons, interestingly, showed long onset-latencies at stimulation. During the experiments, the dishes where cells were plated were continuously perfused with saline and the exchange of bath solution for odorant solutions was completed within ten seconds. Thus, the location of neurons in dishes is probably not responsible for this latency. A possible explanation for the latency in response is the involvement of a diffusible messenger(s) such as NO. A diffusible messenger which is probably released following stimulation might cause $\left[\mathrm{Ca}^{2+}\right]_{\mathrm{i}}$ increases in neighboring neurons.

In this study, we directly measured the odor-evoked responses of single ORNs of insect using the cultured antennal neurons of blowflies, and demonstrated that at least three cellular messengers, cAMP, cGMP and $\mathrm{Ca}^{2+}$, mediate the responses of these cultured antennal neurons.

ORNs of insects as well as vertebrates are exposed to many kinds of odors, and they distinguish important ones for foraging, mating or egg-laying from many others. Various intra- and intercellular mechanisms which are closely connected to each other probably regulate ORNs. Further investigations on cultured antennal neurons using optical or patch-clamp recording methods will provide more information on the physiological properties of ORNs and might also resolve the question of whether ORNs of insects as well as vertebrates discriminate between different odor stimuli before information is sent to the central nervous system.

\section{REFERENCES}

Al-Mohanna FA, Cave J, Bolsover SR (1992) A narrow window of intracellular calcium concentration in optimal for neurite outgrowth in a rat sensory neurons. Dev Brain Res 70: 287-290
Boekhoff I, Tareilus E, Strotmann J, Breer H (1990) Rapid activation of alternative second messenger pathways in olfactory cilia from rats by different odorants. EMBO J 9: 2453-2458

Breer H, Boekhoff I, Tareilus E (1990) Rapid kinetics of second messenger formation in olfactory transduction. Nature 345: 65-68

Breer H, Klemm T, Boekhoff I (1992) Nitric oxide mediated formation of cyclic GMP in the olfactory system. NeuroReport 3: 10301032

Connor JA (1986) Digital imaging of free calcium changes and spatial gradients in growing processes in single, mammalian central nervous system cells. Proc Natl Acad Sci USA 83: 6179-6183

Firestein SF, Picco C, Menini A (1993) The relation between stimulus and response in olfactory cells of the tiger salamander. J Physiol 468: $1-10$

Frings S, Lidemann B (1990) Current recording from sensory cilia of olfactory receptor cells in situ. I. The neuronal response to cyclic nucleotides. J Gen Physiol 97: 1-16

Kater SB, Mills LR (1991) Regulation of growth cone behavior by calcium. J Neurosci 11: 891-899

Lischka FW, Schild D (1993) Effects of nitric oxide upon olfactory receptor neurons in Xenopus laevis. NeuroReport 4: 582-584

Mattson MP, Kater SB (1987) Calcium regulation of neurite elongation and growth cone motility. J Neurosci 7: 4034-4043

Nakagawa A, Iwama A (1995) Dissociated neurons of the pupal blowfly antenna in cell culture. Tissue \& Cell 27: 603-612

Nakamura T, Gold GH (1987) A cyclic nucleotide-gated conductance in olfactory receptor cilia. Nature 325: 442-444

Pace U, Hanski E, Salomon Y, Lancet D (1985) Odorant-sensitive adenylate cyclase mediates olfactory reception. Nature 316: 255258

Raming K, Krieger J, Strotmann J, Boekhoff I, Kubick S, Baumstarkm C, Breer H (1993) Cloning and expression of odorant receptors. Nature 361: 353-356

Restrepo D, Miyamoto T, Bryant BP, Teeter JH (1990) Odor stimuli trigger influx of calcium into olfactory neurons of the channel catfish. Science 249: 1166-1168

Ronnett G, Cho H, Hester LD, Wood SF, Snyder SH (1993) Odorants differentially enhance phosphoinositide turnover and adenylyl cyclase in olfactory receptor neuronal cultures. J Neurosci 13: $1751-1758$

Sato T, Hirono J, Tonoike M, Takebayashi M (1991) Two types of increases in free $\mathrm{Ca}^{2+}$ evoked by odor in isolated frog olfactory receptor neurons. NeuroReport 2: 229-232

Sicard G (1985) Olfactory discrimination of structure related molecules: receptor cell responses to camphoraceous odorants. Brain Res 326: 203-212

Sklar PB, Anholt RRH, Snyder SH (1986) The odorant-sensitive adenylate cyclase of olfactory receptor neurons. J Biol Chem 261: 15538-15543

Stengl M (1993) Intracellular-messenger-mediated cation channels in cultured olfactory receptor neurons. J Exp Biol 178: 125-147

Stengl M (1994) Inositol-trisphosphate-dependent calcium currents precede cation currents in insects olfactory receptor neurons in vitro. J Comp Physiol A 174: 187-194

Stengl M, Zufall F, Hatt H, Hildebrand JG (1992) Olfactory receptor neurons from antennae of developing male Manduca sexta respond to components of the species-specific sex pheromone in vitro. J Neurosci 12: 2523-2531

Suzuki N (1989) Voltage- and cyclic nucleotide-gated currents in isolated olfactory receptor cells. In "Chemical Senses Vol 1" Ed by Brand JB et al., Marcel Dekker Inc, New York \& Basel 469-494

Ziegelberger G, van den Berg MJ, Kaissling K-E, Klumpp S, Schultz JE (1990) Cyclic GMP levels and guanylate cyclase activity in pheromone-sensitive antennae of the silkmoths Antheraea polyphemus and Bombyx mori. J Neurosci 10: 1217-1225 